\title{
The directors' roles in containing the Robben Island Diversity Experience (RIDE)
}

\author{
Authors: \\ Frans Cilliers ${ }^{1}$ \\ Michelle May ${ }^{1}$ \\ Affiliations: \\ ${ }^{1}$ Department of Industrial \\ and Organisational \\ Psychology, University of \\ South Africa, South Africa \\ Correspondence to: \\ Frans Cilliers \\ Email: \\ cillifvn@unisa.ac.za \\ Postal address: \\ PO Box 392, Unisa 0003, \\ South Africa \\ Dates: \\ Received: 31 May 2011 \\ Accepted: 24 Oct. 2011 \\ Published: 19 Mar. 2012 \\ How to cite this article: \\ Cilliers, F., \& May, M. (2012). \\ The directors' roles in \\ containing the Robben Island \\ Diversity Experience (RIDE). \\ SA Journal of Industrial \\ Psychology/SA Tydskrif vir \\ Bedryfsielkunde, 38(2), Art. \\ \#986, 10 pages. http:// \\ dx.doi.org/10.4102/sajip. \\ v38i2.986
}

(C) 2012. The Authors.

Licensee: AOSIS

OpenJournals. This work

is licensed under the

Creative Commons

Attribution License.
Orientation: Robben Island represents past denigration and present day liberation. The researchers report on their experiences of containing the learning, consciously and unconsciously, in the Robben Island Diversity Experience (RIDE).

Research purpose: The purpose of the research was to describe the experiences of the directors of RIDE in the last 10 years.

Motivation for the study: Of the many and different diversity events that South African organisations present, RIDE is the only systems psycho-dynamically designed and presented event. This research was an effort to explore the nature of the directors' roles in working with unconscious diversity dynamics in such a provocative venue.

Research design, approach and method: The researchers conducted qualitative, descriptive and double hermeneutic research. The various RIDE events served as case studies. The data consisted of researcher field notes collected during the 10 years. Thematic analysis resulted in four themes, for which the researchers formulated working hypotheses. They integrated them into the research hypothesis.

Main findings: Four themes emerged. They were the diversity characteristics of the directors as containers, working on the boundary between RIDE and the macro role players, attacks on the programme as container and challenges from participants.

Practical/managerial implications: The research highlighted the important roles of directors' authorisation as a resilience factor in containing RIDE.

Contribution/value-add: The research contributed towards the awareness of intergroup relations between role players during diversity dynamic events and of how authorisation cements relationships.

\section{Introduction}

Presenting and attending diversity dynamic workshops in any South African organisation create anxiety. Whilst workshop evaluations normally record the anxiety of the participants, they often do not investigate the experiences of the presenters. This research revealed how unconscious elements from below the surface of the system undermine the tasks and roles of the directors of these psychodynamic events. These elements include the venue, weather, the programme, participants and colleagues.

Curiosity from colleagues in international diversity forums triggered the research. They often ask the researchers about their South African diversity consultations. The pertinent questions they ask include what makes South African diversity dynamics different from those of other countries and what the experience is like to direct diversity events from a group relations perspective.

The researchers realised that these events pose unique challenges, especially when presented on Robben Island as a venue. The researchers have published findings on diversity consultations (Cilliers \& May, 2002), but never related them to the roles of the directors or to containment. This context required an ethno-methodological approach (Henning, 2004).

\section{Robben Island as venue for diversity work}

The researchers have been involved as directors of RIDE for the last 10 years. Although the venue was consciously chosen for marketing purposes, it was only when the work started that it became clear how significantly history and symbols influenced the diversity work unconsciously. Societies have always banished people who represent difference to far away continents (like 
Africa, Australia or America) or to islands (like Alcatraz and Robben Island).

Robben Island first housed rebellious leaders who created opposition on the mainland, then the chronically sick like lepers and the mentally ill and, finally, many political activists and prisoners like Mandela who resisted the apartheid system (Boddy-Evans, 2011). It seems that society felt contaminated by these groups. They provoked anxiety to such an extent that society needed to move their threat to a safe and protected island 14 kilometres away from the mainland for example.

Many interpreted this as society's anxiety about the differences and opposition that it had to defend itself against (see Blackman, 2004) by projecting its anxiety onto the people who present the threat. In order to stay pure and comfortable, society denied their presence and removed them from its consciousness. Therefore, those who represent difference live on the island and one does not have to integrate them into the self (Campbell \& Groenbaek, 2006). Many hypothesised that people used Robben Island as a space in their minds (Diamond \& Allcorn, 2009) to contain impurity and the threat to White supremacy as well as to protect the ideology of apartheid so that life could continue normally on the mainland (May \& Cilliers, 2000).

After the release of the last political prisoners in 1991, Robben Island became a South African museum and a symbol of freedom (Robben Island, 2011). It houses the old prison buildings, a Moslem shrine, a guesthouse and accommodation for the managers, employees and their families. People also know the island for its penguin breeding community, antelope and rabbits. Many local and overseas tourists visit the island by boat every day to see Nelson Mandela's prison cell. For many it is a pilgrimage. Many hypothesised that, where Robben Island had previously represented impurity and the containment of denigration, after 1994 it became the symbol of hope and containment of the new South African ideal of accepting difference and including all previously segregated groups (see Cilliers \& May, 2002).

Robben Island has changed from being a dumping ground linked to denigration to a world heritage site associated with Nelson Mandela's walk to freedom.

\section{The Robben Island Diversity Experience}

This six-day event has occurred annually in November since 2000. Organisations responsible for managing diversity and creating equal employment opportunities attend it voluntarily. Its directors plan and present RIDE as a group relations training event (see Brunner, Nutkevitch \& Sher, 2006; Cytrynbaum \& Noumair, 2004; Fraher, 2004). It consists of a plenary, large and small study groups, intergroup and institutional events as well as review and application events. Its primary task is to study diversity dynamics that manifest in the here-and-now. It employs systems psychodynamically informed consultants. It is important to bear in mind that the representatives and staff (consultants, directors and administrators) are all participants in RIDE.

\section{The systems psychodynamic perspective}

RIDE is a group relations training event. Therefore, its directors present it from a systems psychodynamic consultancy stance (Klein, 2005; Neumann, Kellner \& Dawson-Shepherd, 1997). It incorporates Freud's systemic psychoanalysis (1921), the work of Klein (1997) on family psychology, Ferenczi on object relations and Bertalanffy on systems thinking (Gould, Stapley \& Stein, 2004).

Five assumptions form the basis of the systems psychodynamic consultancy stance. They are the cornerstones for studying relationships in systems (Hirschhorn, 1993; Obholzer \& Roberts, 1994). These assumptions are dependency, fight or flight, pairing (Bion, 2003), me-ness (Turquet, 1974) and weness (Lawrence, 1999).

Its primary task is to push the boundaries of awareness to understand the deeper and covert meaning of organisational behaviour better. A developmentally focussed, psychoeducational process for understanding the deep, covert (unconscious) and dynamic behaviour in the organisational system operationalises it. It includes the challenges of management and leadership (Armstrong, 2005; Lawrence, 2000), boundaries, roles and role configurations, structure, organisational design, work culture and group processes (Czander, 1993; Huffington, Armstrong, Halton, Hoyle \& Pooley, 2004).

Researchers have published systems psychodynamic studies on diversity internationally (Foster, 2004; Foster, Dickinson, Bishop \& Klein 2006; Levine, 2002; McRae \& Short, 2010; Nichols, 2004; Skolnick \& Green, 2004; White, 2006). Others have published the experiences of participants in United Kingdom (UK) events (Brunner, Nutkevitch \& Sher, 2006) and the role of directors in United States of America (USA) events (McRae, 2004). South African research (Cilliers \& May, 2002; De Jager, Cilliers \& Veldsman, 2004; Pretorius, 2003) has shown that the experiences differ because of the ever-present diversity issues that underpin life in South Africa. The purpose of the current research was to describe the experiences of the directors of the Robben Island Diversity Experience in the last 10 years. Therefore, the research addressed the gap in the literature on the unconscious containment role of the directors in the complexity of a diversity event at a venue loaded with symbolism, like Robben Island.

\section{Diversity described}

Diversity issues have challenged organisations for many years (Cray \& Mallory, 1998). Diversity phenomena have multiplied in modern organisations because of democratisation and the human rights movement (Levine, 2002; Thomas, 2001), globalisation (Codrington \& GrantMarshall, 2005) and generational factors (Cross, 2000; Holvino, 2003; Maier, 2002). 
These dynamics also apply to South African organisations (Booysen, 2005; Human, 2005; Pretorius, 2003). The business imperative for managing and embracing diversity lies in improving relationships and business results (Human, 2005; Kandola \& Kandola, 1995). According to Coetzee (2007), these relationships become more complex when and where diversity dimensions, like race, gender and generation, enter the picture. The literature on diversity is confusing because of its vast number of definitions and their lack of integration (Thomas, 2001). Related but different concepts like 'diversity management', 'valuing diversity', 'multiculturalism', 'affirmative action' and 'employment equity' (Cross, 2000; Human, 2005; Miller \& Katz, 2002) also confuse the concept of diversity. In practice, the view that one can train diversity mechanistically if only everyone will accept others increases the confusion. This denies the complex and dynamic nature of diversity and its constant evolvement as society redefines itself. The confusion may also reflect society's ambivalence about keeping (or containing) sameness and difference at bay.

One can define diversity as the presence of people in one social system, being similar and different at the same time, with subjective identities based on their unique conscious and unconscious dimensions (Arredondo, 1996; Coetzee, 2007; Griggs \& Louw, 1995; Thomas, 1996). Reece and Brandt (1993) refer to primary and secondary dimensions of diversity. The primary dimensions refer to core individual attributes that one cannot influence or change, like age, gender, race, ethnicity, physical appearance or traits and sexual orientation. These form the self-images of people and act as filters through which they see and experience the world. The secondary dimensions are changeable and include physical or mental capability, communication style, education, social relationships, marital or parental status, religious beliefs, career, work experience and income. These dimensions add complexity to the self-images of people.

The interaction between the primary and secondary dimensions shapes the values, priorities and perceptions of people. The assumptions are that these identities influence organisations' products and services as well as individual, interpersonal, intra and intergroup and organisational activities (Abdelsamad \& Sauser, 1992; Cox \& Blake, 1991; Holvino, 2003) and that effective human relationships between diverse members of organisations are possible only when they accept and value their differences (Wheeler, 1996). Diversity is not synonymous with differences but includes differences and similarities.

\section{The South African diversity challenge}

On the macro level, globalisation and democratisation are the most important forces that are changing the face of the workforce in South Africa and the customers it serves (De Jager, Cilliers \& Veldsman, 2004; Myburg, 2006; Pretorius, 2003). Africanisation is increasing the complexity of globalisation (Coetzee, 2007).
During the apartheid era, the South African corporate world was almost exclusively Western in its focus and separate from the rest of Africa. The new government started building strong political and economic connections with neighbouring and mid-African states after 1994. Political democratisation has changed the workplace from a mainly homogenous (White male) to an increasingly multicultural and diverse workforce. The quickly growing Black middle class has changed customer demographics and expectations as well as the ways in which organisations do business.

On the micro level, specific diversity factors are influencing South African society and challenging organisations to merge their differences into a corporate culture that is accessible to all its diverse groups. These include its historical and inherent diversity, ethnicity, religion, the Human Immunodeficiency Virus (HIV) and the Acquired Immunodeficiency Syndrome (AIDS), the economy, legislation, social and organisational aspects (see Coetzee, 2007).

Historically, the country has experienced many diverse and unresolved emotions from the apartheid era that racial segregation, minority domination and inhumane acts characterised (Human, 2005). The Truth and Reconciliation Commission (TRC) acted as a facilitator for Black voices and allowed White people to escape from their state of denial (Asmal, Asmal \& Roberts, 1997). Nevertheless, the diversity discourse remains filled with high levels of anger, hate and emotional baggage. These emotions imprison citizens privately and in the workplace (Cilliers \& May, 2002).

The country is one of the most diverse in the world (Cilliers \& Stone, 2005; Maier, 2002). Employees bring their diversity into their organisations (Cilliers, 2004). It includes their social and cultural backgrounds, religious practices, rites of passage according to ethnic or religious roots, perceptions about politeness, social correctness, generosity and time, languages, dietary laws, dress codes and cultural taboos. Intolerance of differences leads to discomfort, disrespect and strong feelings of racial fear, anger, resentment, conflict, competition, hurt, hopelessness and helplessness amongst employees (Cilliers \& May, 2002; Pretorius, 2003). Furthermore, the new legislation and policies for employment equity and affirmative action brought a new kind of competition into the workplace, where emotional and economic survival seems tenuous to all.

After the first democratic election in 1994, many large South African organisations introduced diversity management programmes designed around some of the diversity factors (see Coetzee, 2007). Mostly, they have designed the programmes eclectically from many and mixed paradigms using mechanistic 'exercises', the basis of which are assumptions that one can train diversity and control the outcomes. Research on these programmes showed that they had no effect on diversity awareness (Cavaleros, Van Vuuren \& Visser, 2002).

Organisations present other diversity programmes from a systems psychodynamic consulting stance using group relations training methodology. According to this view, 
the programmes and their workshops act as microcosms of organisational diversity dynamics. This means that the macro organisational diversity issues will play out in the micro workshop here-and-now events (Czander, 1993).

Research on the effect of these programmes shows some movement towards becoming aware of diversity issues on the conscious and unconscious systemic levels. The success of these programmes lies in their focus on the ownership of projections onto and into 'the other', authorising the subsystem to take a leadership role and to move from the paranoid-schizoid to the depressive position (Cilliers \& May, 2002; Cilliers, Rothmann \& Struwig, 2004; Coetzee, 2007; Myburg, 2006). The roles and competence of diversity consultants are crucial in facilitating this movement. It implies a high level of awareness of the consultant's own diversity representation 'as an object' (see Klein, 1997) and competence in working in the field of systems psychodynamics and the human relations training model (Hirshhorn, 1997). On the other hand, organisations need to understand the model's assumptions and systemic, dynamic ways of working whilst not expecting clear predetermined training outcomes.

\section{Core research problem and research objectives}

The core research problem is that experiential events in diversity dynamics are present in South African organisations. There is also some information about the participants' experiences of them. However, there is no knowledge of the roles of the directors of these events or of how contexts, preparation, programmes, participants and colleagues influence their roles during the events. The objectives of this research were to explore these issues and to report on the containment experiences of the two researchers in their roles as directors of these events.

\section{The potential value-add of the study}

The potential value of the research is to provide evidence of the effect of these contextual and programmatic factors so that future directors become aware of these dynamics when planning and presenting effective group relations orientated diversity dynamic events.The structure of rest of the article follows.

The researchers present the research design with reference to the research approach and strategy. The research method follows. It consists of the setting, the roles of the researchers, the sampling method, data collection, recording and analysis. The researchers then mention the strategies they used to ensure quality data and present their findings as manifested themes. The discussion contains the research hypothesis. The conclusion, recommendations, limitations of the study and suggestions for further research conclude the article.

\section{Research design Research approach}

The researchers chose a qualitative, descriptive and ethnomethodological approach (De Vos, Strydom, Fouché \& Delport, 2002; Henning, 2004). They used phenomenological reduction (Alvesson \& Sköldberg, 2010) to study the experience of diversity dynamics. Therefore, the findings tried to answer the 'how' and 'why' questions of diversity experiences in a thick, rich and varied description, although it was not necessarily well-substantiated (Alvesson \& Sköldberg, 2010).

The researchers chose hermeneutics as the research paradigm (Terre Blanche, Durrheim \& Painter, 2006). This allowed an understanding of the directors' diversity experiences. Double hermeneutics (Clarke \& Hoggett, 2009) allowed the researchers to interpret the data from the systems psychodynamic stance in an attempt to develop knowledge about the conscious and unconscious manifestation of diversity dynamics.

\section{Research strategy}

The researchers treated several cases of RIDE events, which spanned ten years, as a single case study (Chamberlayne, Bornat \& Apitzsch, 2004). They used a case study for its instrumental value - to gain an understanding of directorship in a diversity dynamic event and to elaborate on, and extend, the relevant theory (see Denzin \& Lincoln, 2005).

\section{Research method}

\section{Research setting}

The research was set within diversity management as an organisational development (OD) activity. The context was the annual Robben Island Diversity Experience over the last ten years, and specifically the experiences of the directors of the events. The hosting consultancy organisation authorised the directors to manage the group relations aspects of RIDE.

\section{Entrée and establishing researcher roles}

The researchers commented on their 'here-and-now' director roles in the 'there-and-then'. Both researchers have been directors of RIDE several times. This means designing, planning and directing the annual RIDE.

Both researchers had special training relevant to this research, as explicated in the group relations training and systems psychodynamic literature (see Cytrynbaum \& Noumair, 2004; Fraher, 2004), with regard to background and behaviour. Both researchers are psychologists (industrial and clinical) and are system psycho-dynamically informed consultants because of their special training and experience in the relevant consulting and research methodology. They played their directing roles in an appropriate 'professional' manner, as Brunner, Nutkevitch \& Sher, (2006) described. This means:

- remaining within the appropriate role boundaries

- being responsible for what one says and how one behaves

- being able to differentiate between person and role

- being able to differentiate between task and personal needs

- being able to recognise when personal feelings are affecting role performance 
- being able to realise that making mistakes is less important than being able to recover from them.

They also attended to the ethics that this role implies (see Clarke \& Hoggett, 2009). In their researcher roles, they positioned themselves as defended subjects (Boydell, 2009). This refers to their ongoing openness about their own unconscious and inter-subjective dynamics (like transference, counter transference and projective identification) and how these affected the research relationship. This positioning is useful for understanding how disavowed experiences are placed in objects, including the researcher. Their roles required using their own subjectivity, curiosity, intrigue and suspicion as vehicles of inquiry into the manifesting behavioural dynamics in the total system (Alvesson \& Sköldberg, 2010).

\section{Sampling}

The researchers used convenience sampling (Brewerton \& Millward, 2004). The two researchers, in their roles as directors of RIDE, used their own ethnographic experiences (Henning, 2004).

\section{Data collection methods}

Following the guidelines in the literature (see Chamberlayne, Bornat \& Apitzsch, 2004; Holloway \& Jefferson, 2010), the researchers collected the data from their RIDE files and their individual and collective memories. Their first task was to write essays separately on their RIDE experiences to answer the question: 'What is my background as a South African citizen and how did that influence my role as director of the RIDE'?

Their second task was to work separately through their RIDE files to refresh their memories about the various events they directed and to come up with significant vignettes around containment. The files contained their design, planning and directing field notes, email correspondence with the host organisation and invited staff members, the participants' inquiries, the programmes, RIDE staff meeting agendas and minutes, processed data as well as notes after small, large and intergroup sessions.

Their third task was to share the outcomes of the first two tasks with each another and to choose the most appropriate vignettes for analysis.

\section{Recording of data}

The researchers typed the vignettes and essays and kept them secure.

\section{Data analyses}

The researchers used thematic analysis (Brewerton \& Millward, 2004; Camic, Rhodes \& Yardley, 2003; Denzin \& Lincoln, 2005), from which four themes emerged. They then used double hermeneutics (Clarke \& Hoggett, 2009) to interpret the data from the systems psychodynamic consultancy stance (Armstrong, 2005; Campbell, 2007; Cilliers \& Koortzen, 2005; Gould, Stapley \& Stein, 2004;
Huffington, et al., 2004; Klein, 2005). They integrated the data into different working hypotheses and a research hypothesis (Schafer, 2003).

\section{Strategies employed to ensure quality data}

The researchers ensured scientific rigour by focusing on validity, reliability, transferability and ethics (Denzin \& Lincoln, 2005; Terre Blanche, Durrheim \& Painter 2006). They ensured reliability and dependability by planning and executing the research project carefully. An example is the way that they gathered the data and conducted their analysis.

The researchers based the trustworthiness of the data on credibility and validity (Denzin \& Lincoln, 2005). They believed that their research was strong in its in-depth (psychological) description. This revealed the complexities of the variables and their interactions from a systemic and psychodynamic perspective.

Furthermore, both researchers, as knowledgeable and professional practitioners, were involved in all aspects of the research. They remained aware of their different roles, as directors of RIDE and researchers in this project, throughout. Therefore, they could guard against in-authenticity, unconscious collusions and de-authorisation in their roles (Hirschhorn, 1997).

The researchers attended to ethical requirements by not causing any harm to the participants or invading their privacy (Denzin \& Lincoln, 2005; De Vos, Strydom, Fouché \& Delport, 2002). They obtained informed consent from all RIDE participants at the start of each event (as a standard procedure) to use the themes that emerged from all the RIDE events for research purposes.

\section{Reporting}

The researchers reported and interpreted their findings by theme. They formulated their working hypotheses by theme and integrated them into their research hypothesis. They then reported their conclusions, recommendations, the limitations of the study and suggestions for further research.

\section{Findings}

Four themes emerged:

- the diversity characteristics of the directors as containers

- working on the boundary between RIDE and macro role players

- attacks on the programme as container

- challenges from participants.

\section{The diversity characteristics of the directors as containers}

The first author's essay read:

'I am a white South African male living in Pretoria. As director, I planned and directed the first RIDE. This created a conscious sense of excitement and expectation of being on an island that I have seen from Bloubergstand as a child on holiday with my 
grandparents. I remember that they referred to the island as a place where people who do not fit into society are kept to protect us from the 'swart gevaar'. On arriving on the island and starting doing the work, I realised to what extent my past and what I represent as an object, played in taking up the role as director in a diversity event within the South African context. In this role, I was challenged by the manager and his colleague ( 2 white males) of the RIDE hosting organisation, as well as two academic colleagues ( 2 white males, both psychologists) (they were all coconsultants in RIDE). It was as if the white males had to fight for the first position on the island that now belonged to white and black South Africans. My work as a directorate pair with Michelle (a black female associate director) was under attacked by participants. In old South African apartheid terms, this is an illegitimate and shameful relationship. It was as if participants unconsciously struggled with the conflict between the old and the new authority configuration. Historically, I am from French Huguenot and Dutch decent. As such I represent the National Party government and its apartheid policy. In the RIDE context I represent the prison wardens who suppressed the imprisoned freedom fighters (like Nelson Mandela). Consciously I experienced being authorised by participants in how they took up their participant roles, although unconsciously I experienced a simmering ganging-up amongst black participants to act out violently against my authority. It was as if black men's script was one of 'you had your chance - now get out of the way' - implying that white leadership has become irrelevant. This experience was strong when some participants revealed that they were actually imprisoned on the island years ago, or when others revealed that their family members died on the island. It was as if the shame of the past had to be carried by me as the white director. When Michelle became the director of RIDE in 2002, I took up the role as associate director. This support role felt more comfortable - as if the South African system felt more comfortable with the white man co-directing a diversity event on Robben Island with all that it represents.' (Author 1, male, RIDE director)

The second author's essay read:

'It is very difficult for me to write about my experiences not because the experiences were that difficult, but because I am challenged to explain my race. In Apartheid South Africa I was classified by the government and society as coloured, but amongst those who were involved in the struggle I was classified as black. In post Apartheid South Africa I am classified as black and further classified as coloured. Within my own community I will be classified mainly as coloured, but by those with a different kind of political consciousness I will be classified as black. Just to add to this, I am also not seen as African, in actual fact the term non-African black has been used to describe me. Thus, my race identity oscillate between being black or coloured, with most in South Africa classifying me as coloured. I grew up in a rural town, Genadendal (Valley of Mercy) one and a half hour drive from Cape Town, as well as in Cape Town. I experienced the political struggle especially during my high school years and to some extent during my tertiary education. I felt that I belonged to Robben Island and that Robben Island belonged to me - that those who were imprisoned on the island was the reason why I could walk onto Robben Island to do diversity work. Thus, I have never wondered whether I belonged on Robben Island, I have wondered, and at times been certain, that I am not qualified to direct RIDE. However, I have taken up the role to the best of my abilities working towards providing a containing RIDE, for staff and participants.' (Author 2, female, RIDE director)

\section{Working on the boundary between the Robben Island Diversity Experience and macro role players}

The daily work routine of the Robben Island managers and staff consists of managing the boatloads of museum visitors from Cape Town. During RIDE, they need to attend to extra demands around conferencing. Accommodation and meals especially created conflicts between them and RIDE staff. This led to anxiety about containment for the directors and participants.

The hosting organisation approached RIDE from a business, financial and marketing perspective. It also provided a learning container for practitioners to work with diversity dynamics. During the numerous pre-RIDE meetings, the directors explained and negotiated the design and management of RIDE as a group relations event in detail especially the task, time and space boundaries. Despite this, the organisation challenged the directors' authority many times because of the challenges it experienced in hosting RIDE.

\section{Attacks on the programme as container}

Crossing from Cape Town to Robben Island by boat created difficulties and anxiety for the directors. Once, a Black woman member of staff did not arrive in time for the boat's departure, did not answer her cellphone and only arrived the next day with the participants. Whilst the directors were trying to make alternative staffing arrangements, a White woman declared that she did not feel contained and went to read in her room.

On one occasion, the staff could not leave Cape Town harbour because of a fierce storm (the 'Cape Doctor'). Staff had to travel the next day on the same boat as the participants. The wind was still blowing fiercely and many participants fell seasick. During the opening plenary, participants complained about not been able to eat and accused the directors and consultants of cruelty.

On day four of the RIDE, a former prisoner guided participants on a tour of the Robben Island prison. On their return, participants were so emotionally full of diversity issues that they could not work. The directors subsequently changed the programme to leave the evening free for informal processing.

On another occasion, former President Mandela visited the island in preparation for the Fédération Internationale de Football Association (FIFA) World Cup. Participants, and even some staff members, wanted to see Mr Mandela. This would have happened during a small study group session. Participants suggested asking Mr Mandela 'to address us during a large study group'. The directors had to preserve the boundaries and process in the dynamics of a large study group. During Mr Mandela's visit to the island, several participants ran from their sessions but did not see him.

As a director, the second author tried hard to preserve the training group as part of RIDE in order to develop consultants 
in general and to have relief RIDE consultants for the thereand-then-events. Recruiting participants proved difficult and the power struggle with the hosting organisation emerged again.

\section{Challenges from participants}

In an intergroup event a 'woman's group' was working in what used to be the kitchen. It sent two Black women to tell the (White male) director about their hypothesis. The (Black woman) consultant commented that the group was 'sending the maids to do the work on their behalf'. Later, two White women told the director that the group was not working together and that they were frustrated with the Black consultant's interpretations.

In a large study group, a White woman spoke about the difficulty she had in working with the newly appointed Black male manager in her organisation. Her only memory of working with a Black man was the typical colonial scenario of giving orders to her 'garden boy', who stayed in a small room in her back yard.

In an intergroup event, one group which called themselves

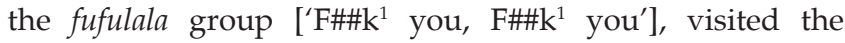
management team to complain about the directors' lack of caring. In the same event, a White man (one of 12 participants from a big mining company) blamed the Black woman director openly and continuously for the poor 'facilitation' from her and the staff.

Some participants who were previously prisoners, or had family members who were prisoners on the island before ('the generals' or 'the Black mafia'), attended RIDE on a pilgrimage to honour the memory of veterans who had struggled and died. They expected the RIDE staff to allow them to be 'on holy ground' and not necessarily to explore diversity dynamics.

Other participants from African countries (Swaziland, Zimbabwe and Nigeria), Europe (The Netherlands and Sweden), the USA and Australia expected to 'learn about diversity' in, and from, 'a country that clearly struggles' with reconciling differences. The intensity of the South African experience and the diversity examples the consultants used in the events steadily silenced their voices.

The last two examples resulted in those on a pilgrimage or from another country beginning to assume academic roles.

\section{Discussion}

The purpose of the research was to describe the experiences of the directors of the Robben Island Diversity Experience in the last ten years. This research was important to enlighten present and future directors of diversity events about the importance of containment to provide a safe learning environment to participants. From a dynamic point of view, these relate to the contextual, programmatic and human factors. The four themes that emerged related to the diversity characteristics of the directors as containers, working on the boundary between RIDE and the macro role players, attacks on the programme as container and challenges from participants.

\section{Interpretation of Theme 1}

The researchers interpreted Theme 1 as showing how the differences between the directors as diversity objects offer different perspectives of containment. In his youth, the White man was the silent observer of the island as a place of danger, whilst the Black woman had a voice in the struggle towards finding her identity. As a director, the White man experienced being challenged and competition from sameness (White men) and difference (Black and female), whilst the Black woman's story was about embracing a previously denied opportunity. The White man's story seemed characterised by sharing the position with the Black woman, whilst the Black woman's story seemed characterised by self-authorisation to provide containment to the other.

\section{Working hypothesis 1}

The two directors' styles represented old and new containment positions (Cytrynbaum \& Noumair, 2004). The old operated from a position of self-protection and 'islandisation' as defences, followed by envy, attack and stepping out of role (see Blackman, 2004), almost like FW de Klerk did as president. The new style of containment is about moving from a struggle for resources and identity to finding a place and making a space for belonging for others.

\section{Interpretation of theme $\mathbf{2}$}

The researchers' interpretation of Theme 2 was that RIDE represented a macro intergroup event with unclear boundaries, unauthorised roles and vast differences in task between the directors, the Robben Island management staff and the hosting organisation. This resulted in power struggles, where the directors were authorised in the group relations event but not in terms of the macro event (Hirschhorn, 1997). With regard to the island managers, the directors' counter transference was that they were standing on 'Mandela's holy ground' and should tread carefully. To the hosting organisation, the counter transference was to 'know your place and leave the business for us to manage' (Clarke \& Hoggett, 2009).

Another interpretation was that the power struggles were a reason for the directors' failure to attend to the consultants' power and rivalry issues (see Gemmill \& Elmes, 1993). The evidence of numerous authority attacks on the directors' authority from staff or consultants suggested rebellious childish responses, maybe because of feelings of neglect (James, 1977). This means that relationship issues around intimacy, connection, rivalry and competition (that the directors could not discuss) were projected outward and contained in the macro relationships (Blackman, 2004; Stapley, 2006). 


\section{Working hypothesis 2}

Presenting a diversity dynamic event in such a provocative venue allows for unexpected power relations about management on a macro level as a defence against attending to, and containing, the group relations consultant team in an appropriate way.

\section{Interpretation of Theme 3}

The researchers' interpretation of Theme 3 was that it showed diversity work on Robben Island to be an impossible task (see Freud, 1921). A comment in the directors' field notes was about how, seen from afar, Robben Island seemed to be drifting in the ocean. It had a sense of an unstable container with a free-floating anxiety (Vansina \& Vansina-Cobbaert, 2008) hovering above it.

The researchers interpreted RIDE as a container and what it represents became larger than the event and the role of directing the event. It seemed that the island had become a type of diversity laboratory where participants acted out their collective unconscious anxiety (Klein, 2005) and memory in various ways. One way was to attack the directors, who had dared to assume an authority role that was different from any roles in their memories. Perhaps the closest role association is that of the previous government. Participants responded to it as the enemy in the mind. More evidence for this interpretation is the effort of the second researcher to secure the training group to benefit future consultants. They could unconsciously represent more prison wardens, as if the unconscious is saying (see Blackman, 2004) that Robben Island is not a training venue - it is a place for honouring the struggle.

\section{Working hypothesis 3}

The system's unconscious attack on the containment boundaries of RIDE targeted the role of the directors as heads of the laboratory that brought foreign cultures to a place that has been associated with struggle for so long. The result was the primitive defence of splitting the known from the unknown (Bion, 2003). It projected the unfamiliar onto the roles of directors and set them up to identify with the projection and, possibly, fail to deliver on the primary task.

\section{Interpretation of Theme 4}

The researchers interpreted Theme 4 as South African domestic scenarios challenging the directors' authority to remain in role when working with familiar family and social dynamics (Cytrynbaum \& Noumair, 2004):

- the White colonial madams reporting the Black maids' unacceptable behaviour to their White husbands

- the rich White suburban madam treating her garden boy as an emotionally-disconnected task object

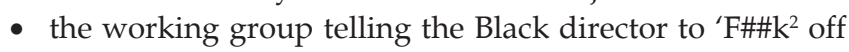
because they do not buy this diversity crap'

- the White miner ganging up with his mates by swearing at

2.The symbol (\#) indicates letters that have been omitted. and accusing the Black woman director of incompetence

- freedom fighters who hang on to and bring their struggle into the workplace

- the foreigners entering the South African workplace and being ignored.

Below the surface (see Huffington, et al., 2004), participants played out typical South African dynamics like White superiority, entitlement, emotional disconnection between races, anger and hostility in the organisational hierarchy between races and xenophobia. This showed that disgust at humour, creativity and survival, which national pride, superiority and ignorance cause, camouflage entitlement (Sievers, 2009).

Although the directors addressed these within the task and time boundaries, their interpretation was that the attacks were also personal and the result of the volatility and tenuousness of the directors' authorisation (Nutkevitch, 2001). The macro and RIDE systems seemed to authorise it although the participants did not always do so. This makes self-authorisation problematic. Containing the anxiety of the RIDE participants, when their own diversity dynamics confront them, is difficult for directors. It may get out of hand. The laboratory feels just as unsafe as real life does.

The researchers interpreted using Robben Island as a venue to study diversity dynamics as a clever marketing strategy. However, it was also a minefield in terms of diversity dynamics. Over the years, the island has developed its own system domain defences (see Bain, 1998) against banishment, denigration, separateness, struggle and death. RIDE played the role of the unwelcome guest. This started the power game.

\section{Working hypothesis 4}

Robben Island, as a symbol, represents 'islandisation' as a defence mechanism (seclusion, remaining separate with stormy, cold water). Because RIDE's identity and primary task did not fit the dominant identity, the island performed its historic primary task of defending against difference and banishing it.

Working hypothesis 4 is that the directors of RIDE face challenges in many conscious and unconscious ways from a complex and interwoven set of domain defences. These take on lives of their own. They include historical and present day events as well as unconscious rules of conduct and alliances that attack the authority of the directors. They appear as conflict, rivalry and envy.

\section{Conclusions}

The researchers concluded that the RIDE participants mirrored historic and present day South African diversity dynamics. They challenged the directors to contain what we normally expect our authority figures (like in our own organisations) to contain on our behalf. The directors' authorisation seems to be the one primary resilient factor in containing RIDE. 
South African diversity dynamics are much more than mechanically 'getting the affirmative action numbers right'. Below the surface, this diversity scenario is packed with history, complex and diverse perceptions and experiences, extreme levels of anger, hate, aggression, competition, rivalry, competition and envy between the different groups. In every RIDE, the researchers experienced how the diversity dynamics change from the last event. It is not easy to see tendencies because of their complexity and the qualitative nature of the work. The effect of RIDE is small on a national and international scale. RIDE discourses often include the Truth and Reconciliation Commission (TRC), which Rev. Tutu chaired (see (Vansina \& Vansina-Cobbaert, 2008). It is the researchers' belief that RIDE offers participants events of intense confrontation with diversity dynamics, opportunities to listen to others and a shift in the quality of the relationships between differences.

The researchers recommended that work on South African diversity should continue using group relations events like RIDE. Its directors should put more effort into linking this work with Tutu's work in the Truth and Reconciliation Commission.

\section{Limitations of the study}

The researchers must mention that they could not capture the vast amount of information from 10 years of RIDE, with so many participants and vignettes, in this article. Nevertheless, the researchers tried to integrate the material as well as their unconscious dynamics allowed them. The other issue that the researchers did not mention was how the RIDE participants were able to really converse, across historical divides, with each other. They were also able to take up new and appropriate roles and to take ownership of their authority appropriately at individual and group levels.

Perhaps the researchers needed space to speak about the more difficult diversity dynamics. This meant that they would not touch on the diversity dynamics of real connections across differences. The researchers can also mention that RIDE was never planned as an event for research. This meant that the researchers reflected on their own experiences within this context. Although the auto-ethno-methodological approach has limitations of extreme subjectivity, it may have been the best option to give the diversity fraternity a sense of the event through the experiences of these two director-researchers. The limitation includes the notion that the discussion is never complete - each experience and hypothesis opens up new possibilities for interpretation. The researchers needed to close the boundary at this point and time.

Future research should study the authorisation of directors in more detail to allow for a better understanding of the dynamics between the macro environment and the RIDE staff, as well as to explore the diversity dynamics of real connections across differences and self-authorisation as a construct.

\section{Acknowledgements Competing interests}

The authors declare that they have no financial or personal relationship(s) that may have inappropriately influenced them in writing this paper.

\section{Authors' contributions}

F.C. (University of South Africa) and M.M. (University of South Africa) contributed equally to the research design, literature and empirical studies.

\section{References}

Abdelsamad, M.H., \& Sauser, W.I. (1992). Managing the diverse workforce. Vinton: Society for Advancement of Management.

Alvesson, M., \& Sköldberg, K. (2010). Reflexive methodology. New vistas for qualitative research. London: Sage.

Armstrong, D. (2005). Organisation in the mind. Psychoanalysis, group relations and organisational consultancy. London: Karnac.

Arredondo, P. (1996). Successful diversity management initiatives: A blueprint for planning and implementation. Thousand Oaks: Sage.

Asmal, K., Asmal, L., \& Roberts, R.S. (1997). Reconciliation through truth: A reckoning of apartheid's criminal governance. Cape Town: David Philip Publishers.

Bain, A. (1998). Social defences against organisational learning. Human Relations, 51(3) 413-429, http://dx.doi.org/10.1023/A:1016952722628, http://dx.doi. org/10.1177/001872679805100309

Bion, W.R. (2003). Learning from experience. London: Karnac.

Blackman, J.S. (2004). 101 Defences. How the mind shields itself. New York: BrunnerRoutledge.

Boddy-Evans, A. (2011). Cape Town.s infamous Robben Island. Retrieved 09 May 2011, from http://africanhistory.about.com/od/apartheid/p/Robbenlsland.htm

Booysen, L. (2005). Social identity changes in South Africa: Challenges facing leadership. Inaugural lecture, Graduate School of Business Leadership, University of South Africa, 23 June.

Boydell, L. (2009). Analysing discourse psycho-socially. In S. Clarke \& P. Hoggett. Research beneath the surface. Psycho-social research methods in practice. London: Karnac.

Brewerton, P., \& Millward, L. (2004). Organisational research methods. A guide for students and researchers. London: Sage.

Brunner, L.D., Nutkevitch, A., \& Sher, M. (2006). Group relations conferences. Reviewing and exploring theory, design, role-taking and application. London: Karnac.

Camic, P.M., Rhodes, J.E., \& Yardley, L. (2003). Qualitative research in Psychology Washington: APA

Campbell, D. (2007). The socially constructed organisation. London: Karnac.

Campbell, D., \& Groenbaek, M. (2006). Taking positions in the organisation. London: Karnac.

Campbell, D., \& Huffington, C. (2008). Organisations connected. A handbook of systemic consultation. London: Karnac.

Cavaleros, C., Van Vuuren, L.J., \& Visser, D. (2002). The effectiveness of a diversity awareness training programme. South African Journal of Industrial Psychology, 28(3), 50-61.

Chamberlayne, P., Bornat, J., \& Apitzsch, U. (2004). Biographical methods and professional practice. An international perspective. Bristol: Policy Press.

Cilliers, F. (2004). A Person-Centered view on diversity in South Africa. The PersonCentered Journal, 11(1), 33-47.

Cilliers, F., \& Koortzen, P. (2005). Conflict in groups. The CIBART model. HR Future, October, 52-53.

Cilliers, F., \& May, M. (2002). South African diversity dynamics. Reporting on the 2000 Robben Island Diversity Experience. A Group Relations event. South African Journal of Labour Relations, 26(3), 42-68.

Cilliers, F., Rothmann, S., \& Struwig, W.H. (2004). Transference and countertransference in systems psycho-dynamic group process consultation: The consultant's experience. South African Journal of Industrial Psychology, 30(1), consultant $72-81$.

Cilliers, F., \& Stone, K. (2005). Employment equity practices in three South African Information Technology Organisations; A systems psychodynamic perspective. South African Journal of Industrial Psychology, 31(2), 49-57.

Clarke, S., \& Hoggett, P. (2009). Research beneath the surface. Psycho-social research methods in practice. London: Karnac.

Codrington, G., \& Grant-Marshall, S. (2005). Mind the gap! Johannesburg: Penguin Books. 
Coetzee, O. (2007). Exploring interpersonal and inter-group diversity dynamics in South African organisations by means of a theoretical model. Unpublished DCOM South African organisations by means of a the
thesis, University of South Africa, Pretoria.

Cox, T., \& Blake, S. (1991). Managing cultural diversity: Implications for organisationa competitiveness. Academy of Management Executive, 5, 45-56.

Cray, D., \& Mallory, G.R. (1998). Making sense of managing culture. London: International Thomson.

Cross, E.Y. (2000). Managing diversity - the courage to lead. London: Quorum Books.

Cytrynbaum, S., \& Noumair, A. (2004). Group dynamics, organizational irrationality, and social complexity: Group relations reader 3. Jupiter: A.K. Rice.

Czander, W.M. (1993). The psychodynamics of work and organizations. New York: Guilford.

De Jager, W., Cilliers, F., \& Veldsman, T. (2004). Leadership development from a systems psycho-dynamic consultancy stance. South African Journal of Human Resource Management, 1(3), 85-92.

De Vos, A.S., Strydom, H., Fouché, C.B., \& Delport, C.S.L. (2002). Research at grass roots. Pretoria: Van Schaik.

Denzin, N.K., \& Lincoln, Y.S. (2005). The Sage handbook of qualitative research. London: Sage.

Diamond, M.A., \& Allcorn, S. (2009). Private selves in public organisations. The psychodynamics of organisational diagnosis and change. New York: Palgrave.

Foster, A. (2004). Living and working with difference and diversity. Paper presented at OPUS (Organisation for Promoting Understanding of Society), Bloomsbury, London, 14 November.

Foster, A., Dickinson, A., Bishop, B., \& Klein, J. (2006). Difference: An avoided topic in practice. London: Karnac.

Fraher, A. (2004). A history of group study and psychodynamic organisations. London: Free Association.

Freud, S. (1921). Group psychology and the analysis of the ego. Complete works of Sigmund Freud. London: Hogarth.

Gemmill, G., \& Elmes, M. (1993). Mirror, mask, and shadow. Psychodynamic aspects of intergroup relations. Journal of Management Inquiry, 2(1), 43-51.

Gould, L.J., Stapley, L.F., \& Stein, M. (2004). Experiential learning in organisations. Applications of the Tavistock group relations approach. London: Karnac.

Griggs, L.B., \& Louw, L.L. (1995). Valuing diversity. New York: McGraw-Hill.

Henning, E. (2004). Finding your way in qualitative research. Pretoria: Van Schaik.

Hirschhorn, L. (1993). The workplace within: Psychodynamics of organizational life. Cambridge: MIT.

Hirschhorn, L. (1997). Reworking authority. Leading and following in the post-modern organisation. London: MIT.

Holloway, W., \& Jefferson, T. (2010). Doing qualitative research differently. Los Angeles: Sage.

Holvino, E. (2003). Theories of differences: Changing paradigms for organisations. In D.L. Plummer (Ed.), Handbook of diversity management: Beyond awarenes to competency-based learning (pp. 111-132). Lanham, MD: University Press of America.

Huffington, C., Armstrong, A., Halton, W., Hoyle, L., \& Pooley, J. (2004). Working below the surface. The emotional life of contemporary organisations. London: Karnac.

Human, L. (2005). Diversity management for business success. Pretoria: Van Schaik.

James, M. (1977). Techniques in transactional analysis for psychotherapists and counsellors. Reading: Addison-Wesley.

Kandola, R., \& Kandola, P. (1995). Managing diversity: New broom or old hat? In C.L. Cooper, \& I.T. Robertson (Eds.), International Review of Industrial and Organizational Psychology, 10, (pp. 131-167). West Sussex: John Wiley \& Sons.

Klein, L. (2005). Working across the gap. The practice of social science in organisations. London: Karnac.

Klein, M. (1997). Envy and gratitude and other works 1946-1963. London: Hogarth.
Lawrence, W.G. (1999). Exploring individual and organisational boundaries. A Tavistock open systems approach. London: Karnac.

Lawrence, W.G. (2000). Tongued with fire. Group in experience. London: Karnac.

Levine, D.P. (2002). The ethical organisation and the ideal of diversity. International Society or the Psychoanalytic Study of Organisations, 2002 Symposium. University of Denver: Graduate School of International Studies. Winter.

Maier, C. (2002). Leading diversity - a conceptual framework. Bamberg: Difo-Druck.

May, M.S., \& Cilliers, F. (2000). Robben Island: Container for difference. Unpublished manuscript.

McRae, M.B. (2004). Class, race and gender: Person-in-role implications in taking up the directorship. In S. Cytrynbaum \& D.A. Noumair, Group dynamics, organisationnal irrationality, and social complexity: Group Relations Reader 3. Jupiter: AK Rice Institute.

McRae, M.B., \& Short, E.L. (2010). Racial and cultural dynamics in group and organisational life. London: Sage.

Miller, F.A., \& Katz, J.H. (2002). The inclusion breakthrough: Unleashing the real power of diversity. San Francisco: Berrett-Koehler Publishers Inc.

Myburg, H.S. (2006). The experience of organisational development consultants working in the systems psychodynamic stance. Unpublished M.A. dissertation. University of South Africa, Pretoria.

Neumann, J.E., Keller, K., \& Dawson-Shepherd, A. (1997). Developing organisational consultancy. London: Routledge.

Nichols, L. (2004). When faith eclipses hope; forgiveness within reparation. Paper presented at OPUS (Organisation for Promoting Understanding of Society) Bloomsbury, London, 14 November.London.

Nutkevitch, A. (2001). Is containment relevant? Organisational \& Social Dynamics, 2, 270-271.

Obholzer, A., \& Roberts, V.Z. (1994). The unconscious at work. London: Routledge. http://dx.doi.org/10.4324/9780203359860

Pretorius, M. (2003). An exploration of South African diversity dynamics. Unpublished master's dissertation,University of South Africa, Pretoria, South Africa.

Reece, B.L., \& Brandt, R. (1993). Effective human relations. Boston: Houghton Mifflin. Robben Island. (2011). Retrieved 09 May 2011 from

http://en.wikipedia.org/wiki/Robben_Island\#hisrory

Schafer, R. (2003). Insight and interpretation. The essential tools of psychoanalysis. London: Karnac.

Sievers, B. (2009). Psychoanalytic studies of organizations. Contributions from the International Society for the Psychoanalytical Study of Organizations (ISPSO). London: Karnac.

Skolnick, M., \& Green, Z. (2004). The denigrated other: Diversity and group relations. In S. Cytrynbaum \& D.A. Noumair, Group dynamics, organisational irrationality, and social complexity: Group Relations Reader 3. Jupiter: AK Rice Institute.

Stapley, L.F. (2006). Individuals, groups and organisations beneath the surface. London: Karnac.

Terre Blanche, M., Durrheim, K., \& Painter, D. (2006). Research in practice. Applied methods for the social sciences. Cape Town: UCT Press.

Thomas, R.R. (1996). Redefining diversity. New York: American Management Association.

Thomas, R.R. (2001). From affirmative action to affirming diversity. Harvard business review on managing diversity (pp.1-31). Boston: Harvard Business School Press.

Turquet, P.M. (1974). Leadership - the individual in the group. In G.S. Gibbard, J.J. Hartman, \& R.D. Mann, Analysis of groups. San Francisco: Jossey-Bass.

Vansina, L.S., \& Vansina-Cobbaert, M. (2008). Psychodynamics for consultants and managers. From understanding to leading meaningful change. Chichester: WileyBlackwell.

Wheeler, M.L. (1996). Corporate practices in diversity measurement. The Conference Board report no 1164-96-RR. New York: The Conference Board Inc.

White, K. (2006). Unmasking race, culture and attachment in the psychoanalytic space. What do we see? What do we think? What do we feel? London: Karnac. 